\title{
The violence and its implications for health and nursing
}

\author{
Maria Lúcia do Carmo Cruz Robazzi
}

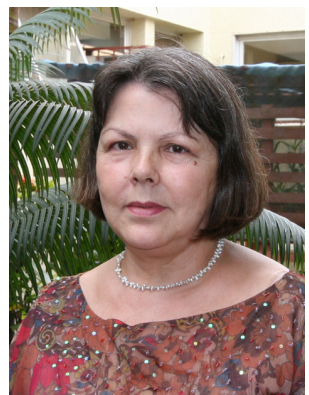

Violence represents a physical or moral constraint, a material or moral force used against the person's will or freedom; it is influenced by places, circumstances, different times and realities ${ }^{(1)}$. It implies in the existence of asymmetrical power relationship with the force being used against the rights, laws and freedom; it is present in all areas of life and manifests itself in different forms such as physical, psychological and social violence $^{(2)}$. It is likely to happen in the workplace among colleagues and/or supervisors, schools, peers and/or professors, and other social environments, including home, among family members.

The issue of violence has become a major concern not only in Brazil but also in many countries because it is a phenomenon of public interest due to its high frequency and the consequences caused in people's lives, especially those living in large urban centers. The increase in everyday violence appears as a representative and problematic aspect of the current organization of social life. Homicides in Brazil rose from 13,910 cases in 1980 to 49,932 cases in 2010, which corresponds to an increase of $259 \%$, a growth of $4.4 \%$ per year. The country's population, however, also increased, at a lower rate (60.3\%), from 119.0 million of inhabitants in 1980 to 190.7 million in $2010^{(3)}$.

Violence because of external causes has also presented alarming rates, especially regarding traffic accidents, which have triggered preventive actions, aiming at greater traffic safety and the development of specific protocols for care to victims at health institutions.

According to the Pan American Health Organization, the interface between violent acts and health exists because it is in the health sector that cases resulting from these acts end up converging ${ }^{(4)}$. It became relatively common for professionals in health institutions to face victims of violence such as children, adults, older people, men and women, often with multiple injuries, pain, irreversible damages, both in physical and mental aspects. At the same time, these professionals are also victims of violence and, sometimes, perpetuate it. Therefore, the violence has been established as an important research topic.

In this issue, interesting studies on nursing care, trauma victims and aspects of domestic violence are presented.

Increased visibility and consequent discussion of the phenomenon of violence will certainly contribute with indicators to minimize this problem. 


\section{References}

1. Minayo SMC, Souza RE, organizadoras. Violência sob o olhar da saúde. Rio de Janeiro (RJ): Fiocruz; 2003.

2. Santos J, Dias C. Violência no trabalho: uma revisão da literatura. Rev Bras Med Trabalho. jan-mar 2004;2(1):36-54.

3. Waiselfisz J]. Mapa da Violência 2012. Os novos padrões da violência homicida no Brasil [Internet]. São Paulo: Instituto Sangari; 2011. 243 p. [acesso 28 jan 2012].| Disponível em: http://www.sangari.com/mapadaviolencia/ pdf2012/mapa2012_web.pdf

4. Organização Pan-americana da Saúde. Violencia y salud. Washington (US): OPAS; 1994.

Maria Lúcia do Carmo Cruz Robazzi is Associate Editor of the Revista Latino-Americana de Enfermagem, and Full Professor of the Escola de Enfermagem de Ribeirão Preto, Universidade de São Paulo, WHO Collaborating Centre for Nursing Research Development, SP, Brazil. E-mail: avrmlccr@eerp.usp.br. 